\title{
Overview of 71 European community-based initiatives against childhood obesity starting between 2005 and 2011: general characteristics and reported effects
}

Wanda Jose Erika Bemelmans ${ }^{1,3^{*}}$, Trudy Maria Arnoldina Wijnhoven ${ }^{2}$, Marieke Verschuuren $^{1}$ and João Breda ${ }^{2}$

\begin{abstract}
Background: Community-based initiatives (CBIs) on childhood obesity are considered a good practice approach against childhood obesity. The European Commission called for an overview of CBIs implemented from 2005-2011. A survey was executed by the National Institute for Public Health and the Environment of the Netherlands, in collaboration with the World Health Organization Regional Office for Europe. The objective of this paper is to provide an overview of the European CBls, as identified in the survey, presenting their general characteristics, applied strategies (separately for actions targeting the environment and/or directly the children's behaviour) and the reported effects on weight indicators.
\end{abstract}

Methods: Potentially eligible CBIs were identified by informants in 27 European Union countries, Iceland, Liechtenstein, Norway, and Switzerland, and through desk research. School based approaches could be included if they complied with criteria related to being 'community-based'. In total, 278 potential eligible CBls were identified and of these, 260 projects were approached. For 88 an electronic questionnaire was completed; of these 71 met all criteria. The included projects were reported by 15 countries.

Results: $66 \%$ of the 71 CBls implemented actions in more than one setting or throughout the neighbourhood. Most frequently reported environmental actions were professional training (78\%), actions for parents (70\%), and changing the social (62\%) and physical (52\%) environment. Most frequently reported educational activities were group education (92\%), general educational information (90\%), and counselling sessions (58\%). The vast majority (96\%) implemented both environmental and individual strategies and about half of the CBIs reported a public-private partnership. Eight CBls provided evidence supporting positive effects on weight indicators and/or overweight prevalence in a general population of children (aged 6 to $12 \mathrm{yrs}$ ), and one CBI did not support this. Two of those CBls were also conducted among adolescents (aged 12 to 16,5 yrs), but showed no effect in this age-group.

Conclusions: Despite diversity of included CBls, common characteristics were the application of integrated actions at a local level, aimed at changing the environment and the children's behaviour directly. Evidence supporting effectiveness on weight indicators is available, although the design and conduct of most of these studies were suboptimal (i.e. no control group, a small sample size, not random).

Keywords: Children, Obesity, Community health services, Programme evaluation, Effectiveness

\footnotetext{
* Correspondence: wanda.bemelmans@rivm.nl

${ }^{1}$ National Institute for Public Health and Environment (RIVM), Bilthoven, the

Netherlands

${ }^{3}$ The National Institute for Public Health and Environment, Centre for a Healthy Living, PO Box 1, 3720, BA Bilthoven, The Netherlands

Full list of author information is available at the end of the article
} 


\section{Background}

The high prevalence and adverse effects of obesity and overweight are public health concerns. Since 1980, population mean values of body mass index (BMI) has been increasing and about $30-70 \%$ of adults are overweight $\left(\mathrm{BMI} \geq 25 \mathrm{~kg} / \mathrm{m}^{2}\right)$ and $10-30 \%$ of adults are obese (BMI $\geq$ $30 \mathrm{~kg} / \mathrm{m}^{2}$ ) in the European Region of the World Health Organization (WHO). Hence, the situation is considered to be epidemic [1,2]. Estimates of the number of overweight infants and young children in the WHO European Region rose steadily from 1990 to 2008 [2]. In 2007-2008 the prevalence of overweight in 12 European countries ranged between $19-49 \%$ in boys and $18-43 \%$ in girls [3]. The European Commission (EC) and the WHO Regional Office for Europe have alerted that obesity is an urgent issue that requires coordinated action through their respective European policy frameworks $[4,5]$. This was followed by the initiation of a joint project that ran from 2008 to 2011 to monitor progress in improving nutrition and physical activity and preventing obesity in the European Union (EU) [6].

The increasing prevalence of childhood obesity can be a signal of a worsening trend of poor diet and low physical activity level across populations. This emphasizes the need to implement strategies that will promote modification of lifestyle factors, as well as strategies that encompass environmental changes making the healthy choice the easy one. The complex aetiology of obesity and the likeliness of developing bad eating and physical activity habits in early stages of childhood have specifically encouraged the use of community-based initiatives (CBIs) [7]. Obesity cannot be solved by the individual alone and generally requires community actions and multi-sector responses to create a more stimulating social and physical environment [8]. The most effective initiatives are population wide and take an integrated, multidisciplinary, comprehensive and sustainable approach [9]. The concept of CBI is a continuum of WHO's definition of health that encompasses a holistic approach to health paying equal significance to the physical, mental, social and spiritual well-being of individuals. CBI programmes represent integrated bottom-up socioeconomic development models that rely on full community ownership and intersectoral collaboration [10].

A CBI generally involves a complementary range of actions implemented at a local level that address the environment or the community's capacity, and/or the behaviour of individuals directly.

There is scarce evidence regarding effectiveness of CBIs and previous overviews on various childhood obesity interventions contained a minority of European studies $[11,12]$. Therefore, the EC has identified the need for a comprehensive (not necessarily an EU representative) overview of European CBIs (good practice examples) implemented in the period 2005-2011. The National
Institute for Public Health and the Environment (RIVM) of the Netherlands, in collaboration with the WHO Regional Office for Europe, executed a survey aimed at providing this overview.

This paper presents the characteristics and contents of 71 European CBIs for which detailed information was provided during this survey. Firstly, the main settings, target populations, and targeted health objectives are presented. Secondly, the strategies that are applied within these CBIs are presented, separately for strategies targeting the environment and educational strategies directly targeting the children. Thereafter, the degree of comprehensiveness is assessed (e.g. the number of strategies implemented and combined implementation of strategies targeting environment and/or the individual child's behaviour) and presence of 'integrated' and 'intersectoral collaboration' (including public-private partnerships and collaboration with the health care system). Finally, the reported effects on body weight, BMI and/or overweight prevalence are presented. The discussion puts these results in perspective, and reflects on the contribution of CBIs to counteracting the obesity epidemic among European children.

\section{Methods}

\section{Definition of eligible CBIs}

Eligible CBIs needed to comply with the following seven inclusion criteria:

- A health objective targeting nutrition and/or physical activity and/or body weight;

- Include children from 0 to 16 years in their target population;

- Period of implementation between 2005 and 2010 in at least one of the 27 countries that were EU member states at the time the study was conducted (current EU28 minus Croatia) or in Iceland, Liechtenstein, Norway or Switzerland;

- A duration of at least one year;

- Accompanied by a process and/or effect evaluation;

- Involvement of the children or their parents (in case of young children) in planning or execution the CBI;

- Intersectoral collaboration at a local level.

The last two inclusion criteria were based on the general WHO concept for CBIs [10]. The aspects within this concept of 'full community ownership' and 'bottom-up' were operationalized in indicators related to the involvement of the children (target population) or their parents during development or implementation of the CBI. The aspects of 'integrated' and 'intersectoral collaboration' were operationalized by indicators related to the number of local organizations involved in executing the CBI. This either required that activities were implemented in at least two settings within the community and/or that 
more than one (local) policy area was involved, and/or that more than one stakeholder, representing a society partner at the local level, participated in the funding scheme or implementation of the CBI. The present overview also considered schoolbased approaches for inclusion when they complied to the inclusion criteria capturing the aspects of being 'community-based'. For example, to meet the criterion on "intersectoral collaboration", at least one other stakeholder (outside the school) needed to be actively involved in the project.

\section{Procedure data collection}

Data collection was organized in two steps. First, in each of the eligible countries a key informant was identified at a national level. They were identified through the nutrition focal points' network of the WHO Regional Office for Europe for WHO European Member States, and through suggestions from experts and members of the EC High Level Group on Nutrition and Physical Activity. Key informants were asked during April-June 2011 to report on potentially eligible CBIs in their country and to suggest contact persons for each CBI. Simultaneously, potentially suitable interventions were identified through publications from international organizations and EUfunded projects $[13,14]$ and three international databases, namely the Trials Register of Promoting Health Interventions, the Canadian Best Practices Portal, and European Directory of Good Practices. Furthermore, the WHO Regional Office for Europe provided an overview of obesity prevention projects that was prepared in 2008 [15]. As a second step in data collection, the contact persons for the CBIs, which had been identified during the first step, were approached in May - July 2011 with an electronic questionnaire to gather detailed information regarding their $\mathrm{CBI}$.

For this study, no ethical approval was necessary according to the Central Committee on Research involving Human Subjects (http://www.ccmo.nl) of the Netherlands because the questionnaires were not directed at patients/data subjects, no direct health related questions had to be answered and no medical investigation were included.

\section{Number of CBIs}

In total, 278 potential eligible CBIs were identified during the overall survey (detailed information provided in Additional files 1 and 2), and 260 were subsequently approached by e-mail with the electronic CBI questionnaire; for the remaining 18 CBIs, the email address was not functioning and no alternative address or contact person could be identified (annex 1). Out of the total 260, 88 (34\%) completed the electronic CBI questionnaire. However, four of these projects were excluded because they concerned national action plans, one CBI was excluded because the reported period of implementation fell outside the 2005-2011 time period, and 12 projects were excluded because they did not meet all inclusion criteria (detailed information provided in Additional files 1 and 2). For the present paper, $71 \mathrm{CBIs}$ therefore have been included, which were executed in 15 European countries (Figure 1).

\section{Questionnaire on CBI characteristics}

The electronic CBI questionnaire included 36 questions, divided in six sections:

1) General characteristics (such as title of CBI, location, target population, implementation period, use of theoretical models);

2) Settings and organizational structure;

3) Objectives;

4) Actions performed in the CBI, which were subsequently grouped in strategies that target the community's capacity or the physical or social environment, and educational activities that can influence the child's individual behaviour more directly and for which the children agree to get actively involved;

5) Process and effect evaluation, costs, transferability and lessons learned; and

6) Questions on how the respondents (i.e. CBI contact persons) completed the questionnaire and availability of (national) databases.

Almost all questions were pre-coded and open questions were available for additional information. We refer to the survey report for the complete questionnaire [14]. Prior to implementation the questionnaire was pilot tested by two invited experts and members of the project team. The questionnaire was available only in English. Here below, detailed information is provided for the questions that were used for the analyses for the present paper.

\section{Settings, target population and objectives}

The CBI questionnaire asked for the main and additional settings where intervention strategies were organized, using the following pre-coded settings: neighbourhood, health care centres, sports facility (e.g. fitness centre, soccer club, dance studio), school, nursery/kindergarten, and 'other'. The main setting should be the setting where most activities concentrate. In case activities are spread throughout the whole neighborhood by multiple channels (and it is not possible to identify one channel/setting as the main one) we asked to score the "neighbourhood" as the main setting. Next it was asked whether an additional setting is involved, and the same pre-coded possible settings were provided. The 'neighbourhood' could also be reported as an additional setting. Respondents 


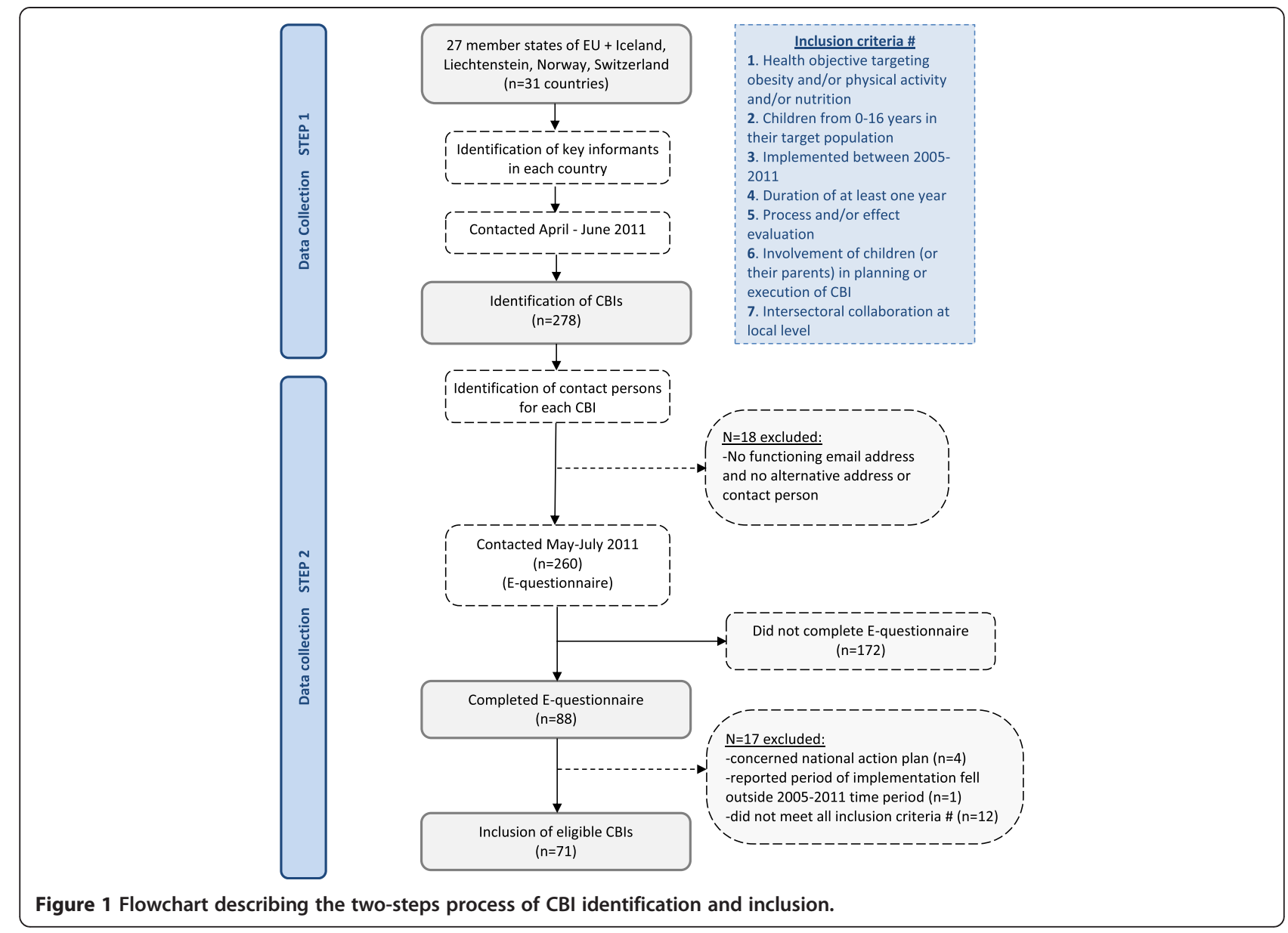

could indicate as many settings as appropriate for their CBI. All CBIs included children in their target population, since this was an inclusion criterion. The specific age range of the children could be reported in an open question. Regarding the objectives, CBI coordinators could score whether their CBI addressed nutrition, and/or physical activity and/or specifically body weight/obesity. This could be specified further in subsequent questions, for example 'healthy diet in general', 'high caloric food items (soft drinks)', 'outdoor play', 'TV watching' or 'self-esteem' (this information is presented only for the CBIs that reported effectiveness).

\section{Environmental strategies and educational activities}

Information on ten pre-coded categories of strategies that could have been possibly used in a CBI to target the physical or social environment and/or community's capacity was collected, as well as information on ten pre-coded activities directly targeted at the children. The strategies and activities that were listed in the questionnaire have been described in detail in the final report of the project [14].

\section{Comprehensiveness of CBIs and integrated action at a local level}

The comprehensiveness of CBIs was assessed by the number of environmental and educational strategies applied in each intervention (see 2.4.2 and 2.4.3). Furthermore, we assessed whether a combination of environmental and educational strategies was applied. As indicators for integrated action we asked for the presence of public-private partnerships and collaboration with regular health care systems. Furthermore, respondents could indicate the collaborating parties at the local level, choosing from the following precoded options:

- (local) policy

- public health organizations (e.g. municipal health services)

- health insurance companies

- community pharmacists

- (paramedical) health professionals

- medical doctors

- food inspectors

- commercial sector involved in food (e.g. shops) or physical activity (e.g. fitness centres) 
- other companies (not directly involved in food or physical activity)

- sport clubs or other associations involved in leisure time activities

- schools (e.g. teachers)

- nursery, (network) of parents

- 'other'.

\section{Effectiveness}

The CBI questionnaire contained dichotomous questions on whether effectiveness was assessed regarding eating habits, physical activity, personal determinants of behaviour (e.g. attitude) and/or body weight. The CBI coordinators were also asked questions regarding study design and effects, and additionally if they could provide references. For the purpose of this article, information was collected from the references provided on body weight, BMI and/or overweight prevalence. Since reports were not always available in English and to be certain that no information was missed, all respondents received an e-mail in July 2011 with questions about the size and age of study population, duration of follow-up measurements, the effects (preferably in means and confidence intervals), and type of measurement (e.g. self-report or measured). In total 62 respondents replied to this e-mail. Regarding the study design the following aspects were considered: sample selection (random yes/no and number of children), comparison with a control condition, follow up period, type of measurement of CBIs' effects, and size and age of the study population. Ultimately, for 14 CBIs information on effectiveness on weight indicators was collected. Seven published their results in a peerreviewed journal. To check representativeness, we screened five meta analyses on obesity prevention or treatment in children, and compared their results on the effectiveness of CBIs on weight indicators with our findings [11,12,16-18]. Waters et al. [11] identified 55 randomized clinical trials (RCTs) on obesity prevention in children, of which 18 were executed in Europe. Three of them were included in this overview [19-21], one was identified, at first, as a potential eligible CBI, but was, nonetheless, excluded based on the equestionnaire because the implementation period was before 2005 [22], four were not identified in our overall survey but if they were they would have been excluded because they were too old, and 10 could have been included in case they fulfilled the CBI criteria. Two of these ten were reported by the key informants, but did not complete the electronic CBI questionnaire. This is coded in annex 1 . The results of these projects and the screening of the other reviews are addressed in the Discussion section.

\section{Analyses}

Descriptive analyses were provided for characteristics of CBIs using the SPSS software package 19.

\section{Results}

Included CBIs: settings, target population and objectives

Table 1 presents the $71 \mathrm{CBIs}$ that were included in the overview.

Figure 2 shows the settings involved separately for main and additional settings. In $48 \%$ of CBIs the school was the main setting and in $76 \%$ the school was involved as any of the settings. About one fourth of CBIs reported that the 'neighbourhood in general' is the main setting. Overall, 66\% of included CBIs implemented strategies in more than one setting or throughout the neighbourhood.

The target population consisted of children or adolescents exclusively in $46 \mathrm{CBIs}$ (65\%) whereas the remaining CBIs (35\%) also targeted persons older than 19 years. The specific age range concerned children younger than 7 years for 6 CBIs, children younger than 13 years for 21 CBIs, adolescents between 13 and 18 years for $1 \mathrm{CBI}$, all children and adolescents (1-19 years) for 14 CBIs, and 25 CBIs reported a mixture of the before mentioned age groups. The specific age range was unknown for four CBIs. Concerning the objectives, 93\% of CBIs specifically targeted nutrition, 90\% physical activity, 52\% body weight and 51\% reported that other lifestyle factors were targeted as well. A combined focus on nutrition and physical activity was applied by $86 \%$ of the CBIs.

\section{Specific strategies used within the CBIs}

The most frequently reported strategies targeting the environment of the children were professional training (75\%), actions for parents (65\%), and actions targeting the social or physical environment (55\% and $49 \%$, respectively). CBIs that reported the "city or neighbourhood" as one of the settings implemented more environmental strategies (except regulation) compared to the CBIs where this was not the case (Figure 3).

Table 2 presents for each of the strategies additional information about the contents of the environmental strategies, as reported by the CBI coordinators.

The most frequently reported educational activities, directly targeting children, were group education (92\%), general educational information (90\%) and counselling sessions by professionals (58\%). Just as for the environmental strategies, a pattern was seen that CBIs that reported the city or neighbourhood as one of the settings implemented activities more often than the other CBIs (Figure 4). The figure shows that all activities, except treatment, were organized in at least one third of the CBIs.

Comprehensiveness and integrated actions at a local level The median number of environmental and educational strategies executed within the CBIs was four and five, respectively, indicating that most $\mathrm{CBIs}$ concerned comprehensive projects implementing diverse strategies at a local level. Almost all CBIs implemented a 
Table 1 List of included projects, specific age range of target populations and settings

\begin{tabular}{|c|c|c|c|c|c|c|c|c|c|c|c|c|c|c|c|}
\hline \multirow[t]{3}{*}{ Country/Project } & \multirow{3}{*}{$\begin{array}{l}\text { Specific } \\
\text { Age range }\end{array}$} & \multicolumn{6}{|c|}{ Settings } & \multirow[t]{3}{*}{ Country/Project } & \multirow{3}{*}{$\begin{array}{l}\text { Specific } \\
\text { Age range }\end{array}$} & \multirow{2}{*}{\multicolumn{6}{|c|}{$\begin{array}{l}\text { Settings } \\
\text { (M = main setting; } \\
{ }^{*}={\text { additional setting })^{1}}^{1}\end{array}$}} \\
\hline & & \multicolumn{6}{|c|}{$\begin{array}{l}(M=\text { main setting; } \\
*^{*}={\text { additional setting })^{1}}^{1}\end{array}$} & & & & & & & & \\
\hline & & $\mathrm{N}$ & $\mathrm{HCC}$ & SPF & $S$ & N/KG & 0 & & & $\mathrm{~N}$ & $\mathrm{HCC}$ & SPF & $S$ & $\mathrm{~N} / \mathrm{KG}$ & 0 \\
\hline Belgium & & & & & & & & Poland & & & & & & & \\
\hline Viasano (EPODE2) & $5-12$ & M & * & * & * & & & $\begin{array}{l}\text { National program } \\
\text { (selected activities) }\end{array}$ & - & & & & M & & \\
\hline Zahnhygiene & $5-8$ & & * & & M & & & Keep fit & $11-15$ & & & & M & & \\
\hline Youth care & $6-18$ & & M & & & & & Romania & & & & & & & \\
\hline Denmark & & & & & & & & Increase access & $3-18$ & & M & & * & * & \\
\hline Copenhagen project & $6-10$ & & & & M & & & SETS & $0-12$ & & & * & M & & \\
\hline Diet in a nutshell & $0-18$ & * & & $*$ & M & * & & Spain & & & & & & & \\
\hline France & & & & & & & & Educacion par & $5-14$ & $*$ & * & & M & & \\
\hline ICAPS & $6-16$ & * & & & M & & & Integral plan & $1-18$ & M & * & & * & $*$ & \\
\hline EPODE & $5-12$ & M & & * & * & * & & THAO & $0-12$ & $*$ & $*$ & & M & * & \\
\hline Plan obesite (Arnaud) & $0-18$ & M & * & * & * & & & Molina de Segura & $1-16$ & $*$ & * & & M & * & \\
\hline Germany & & & & & & & & Delta & $6-16$ & $*$ & $*$ & * & M & & \\
\hline Besser essen ... & - & $*$ & & * & M & * & & PAIDO & $6-16$ & $*$ & M & * & & & \\
\hline Lebenslust & - & & & * & * & M & & Program for s & $3-12$ & & & & M & * & \\
\hline Kita vital & $2-6$ & & & & & M & & Moviprogram & $9-13$ & & & & M & & \\
\hline TAFF & $4-17$ & & & & & & M & Projecte (POIBA) & $8-10$ & & & * & M & & \\
\hline Greece & & & & & & & & Prevention escolar & $4-12$ & & & & M & & \\
\hline PAIDEIATROFI & $0-12$ & M & * & * & * & & & Move with us & $6-12$ & & & M & & & \\
\hline Children Study & 10 & & & & M & & & Prevention and & $6-14$ & $*$ & M & & * & * & \\
\hline Hungary & & & & & & & & Sweden & & & & & & & \\
\hline Ecoschool & $6-18$ & & & & M & & & Jönköping county & $0-18$ & M & * & & & * & \\
\hline Happy & $7-14$ & & & & M & * & & Child health/Salut & $0-18$ & & M & & * & * & \\
\hline Go healthy & $3-6$ & * & & & & M & & Parental support & 6 & & & & M & & \\
\hline Iceland & & & & & & & & Health equilibrium & - & M & * & & * & $*$ & \\
\hline $6 \mathrm{H}$ & $6-16$ & & & & M & & & Friska barn & $1-5$ & & & & & M & \\
\hline Everything affects us, especially ourselves & $6-16$ & M & * & & * & * & & Switzerland & & & & & & & \\
\hline Ireland & & & & & & & & Prevention project & $0-3$ & & M & & & * & \\
\hline Action for life & $4-12$ & & & & M & & & Migus Balou & $0-5$ & & M & & & & \\
\hline The Be Active After- & $7-8$ & & & & M & & & United Kingdom & & & & & & & \\
\hline Fresh fruit schools & $5-13$ & & & & M & & & NHS Dudley & $7-13$ & & & M & & & \\
\hline Cook it & $15-16$ & & & & M & & & Villa vitality & $9-10$ & & & M & * & & \\
\hline Netherlands & & & & & & & & Alive and Kicking & $0-19$ & & & M & * & * & \\
\hline Familie lekkerbek & $4-19$ & M & & & & & & Fun4life & $8-16$ & M & & * & * & & \\
\hline Samen gezond & $0-19$ & M & * & & * & & & On the go & $8-16$ & & & M & * & & \\
\hline Gezond gewicht Overvecht & $0-19$ & * & & & M & * & & Integrated obes & $4-17$ & M & & * & & & \\
\hline On the move & $4-12$ & & & & M & & & $\begin{array}{l}\text { Food life } \\
\text { partnership }\end{array}$ & $4-18$ & * & & & M & & \\
\hline Lekker in je vel & $8-12$ & & & & & & M & Five/60 & $8-10$ & & & & M & & \\
\hline Gezondheidsrace & $0-18$ & M & & * & * & & & Fit4life & $9-11$ & & & & M & & \\
\hline Wijkgezond Zeist & $0-18$ & M & & * & * & * & & Fun, food, fitness & $5-11$ & M & & & & & \\
\hline
\end{tabular}


Table 1 List of included projects, specific age range of target populations and settings (Continued)

\begin{tabular}{|c|c|c|c|c|c|c|c|c|}
\hline Social activation strategy & $4-16$ & M & & & $*$ & MEND & $2-13$ & M \\
\hline Gezonde slagkracht & $0-18$ & M & * & * & * & $\begin{array}{l}\text { Family lifestyle } \\
\text { (FLIC) }\end{array}$ & $4-8+8-12$ & M \\
\hline B-fit & $0-18$ & & * & * & $M *$ & & & \\
\hline Slagkracht & $0-18$ & & * & * & $M *$ & & & \\
\hline Raalte gezond & $0-18$ & & & & M & & & \\
\hline sCoolsport & $6-18$ & & * & * & $M *$ & & & \\
\hline
\end{tabular}

${ }^{1} \mathrm{~N}=$ Neighbourhood in general; HCC = Health care centre; SPF = Sport facility; S = School; N/KG = Nursery/kindergarten; O = Other; $\mathrm{EPODE}=$ Ensemble Prévenons l'Obesité des Enfant.

an *indicates whether this setting is one of the settings of the $\mathrm{CBI}$; $\mathrm{M}$ indicates the main setting, as reported by the project coordinators in the questionnaire. in bold: the countries.

combination of environmental and educational activities (96\%). Three CBIs reported no environmental strategies, but they executed at least two types of educational activities. About half of the projects $(n=35)$ reported presence of a public-private partnership and most frequently mentioned parties in this partnership were public health organizations, (local) policy institutes, commercial food sector (supermarkets, local shops), companies and/or sports clubs or other organizations involved in leisure time sports activities. In total, $51 \mathrm{CBIs}$ collaborated with the health care sector, and in 35 cases this included medical doctors.

Reported effects, specific $\mathrm{CBI}$ objectives and sustainability Out of 71 CBIs, $70 \%$ reported that effectiveness of their CBI had been or will be assessed with respect to body weight, physical activity, dietary intake, and/or behavioural determinants. The answers to the questionnaire was confirmed only for 13 CBIs by a scientific paper or by the evidence provided in response to the separate e-mail on effectiveness. Ultimately, with respect to body weight, BMI and/or overweight prevalence for nine CBIs data were available for children in the general population (Table 3).

Regarding body weight and/or overweight prevalence, one CBI showed no effect [23] and four CBIs [19,21,24,25] reported favourable differences between the intervention and a control condition after at least 1 year follow-up,

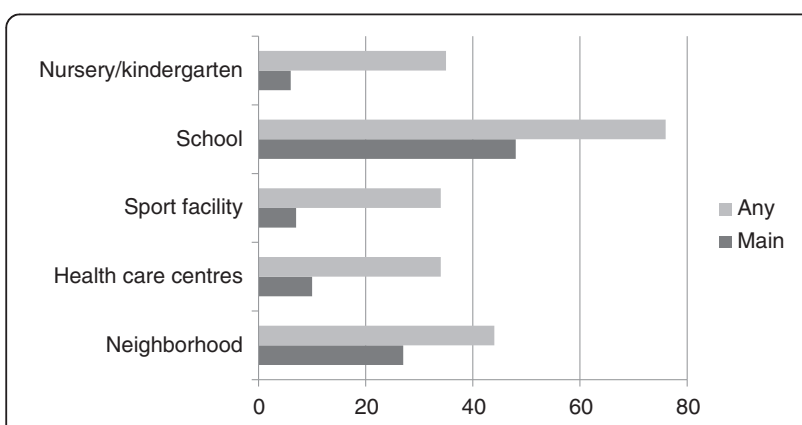

Figure 2 Settings of included community-based initiatives (\% of $71 \mathrm{CBIs}$ ). except one that only did a cross-sectional assessment [24]. In addition, four CBIs showed decreased or stabilized rates of overweight prevalence within their study populations [26-29] (Table 3). Evidence is available exclusively for 6 to 12 year old children. The GO Overvecht Study was effective in these ages, but not among adolescents [27]. Similarly, the CBI in Jönköping County was effective in children but not in adolescents [29]. In overweight or obese children and adolescents, four CBIs ([30-33], Integrated Obesity Care Pathway) reported evidence on effectiveness on the short term, while one of them [33] did not report an effect on overweight prevalence (Table 4). Beneficial effects on BMI did not persist on the long term (after 1-year follow-up period), only a positive impact on waist circumference [31]. Furthermore, it should be noted that most study designs were suboptimal (i.e. not random, small size, no control condition) and three of them [30,33], Integrated Obesity Care Pathway) did not publish their results in a peer-reviewed journal.

Table 5 presents the specific health objectives for nutrition, physical activity and/or body weight of the 13 CBIs of Tables 3 and 4. All CBIs paid attention to both nutrition and physical activity, except two of them who focused solely at physical activity $[19,23]$. CBIs that paid attention to nutrition always specifically highlighted certain healthy food items and discouraged consumption of high caloric food items as part of the nutritional education. Furthermore, they paid attention to various weight related issues, except two of them [24,27].

Related to sustainability of $\mathrm{CBI}$ activities, nine of the thirteen CBIs reported incorporation of their CBI in policy documents beyond the initially planned period. For six of them this included availability of budget [23,21,26,27,29,31]. The other CBIs are still ongoing, except the Children Study [25]. Two CBIs reported incorporation of their approach within usual clinical guidelines [29,33].

\section{Discussion}

Despite the diversity of the included European CBIs, common characteristics were seen regarding the application of integrated actions at a local level, aimed at changing 


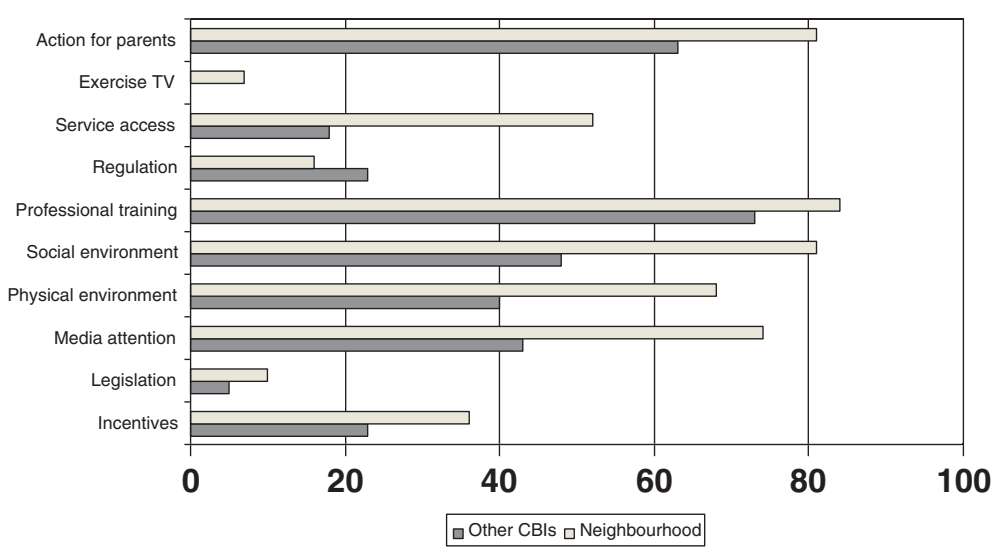

Figure 3 Environmental strategies applied in CBIs that report the neighbourhood as one of the settings versus CBIs where this was not the case (\%).

the environment and the children's behaviour directly. Eight CBIs reported evidence supporting effectiveness on body weight and/or overweight prevalence in a general population of children (aged 6 to $12 \mathrm{yr}$ ), and one CBI did not support this.

\section{Overview of CBIs: general characteristics and applied strategies}

Although multicomponent interventions are encouraged by the ecological framework for decades [34] clear evidence related tothe extent to which the individual or environmental components are working independently or synergistically to influence behaviour change is not available [35]. It is well known though that obesity prevention programmes are sustainable only through on-going support from multiple sectors in society, including parents, teachers, school administrators, private sector and government agencies [9]. All included CBIs in this survey showed intersectoral collaboration, as was confirmed by involvement of multiple settings or the "neighbourhood" to implement various strategies at a local level (65\%), multiple local parties in the funding scheme $(71 \%)$ or multiple parties involved in the organization of the CBI (63\%). So indeed, the included CBIs seem multicomponent interventions, which can potentially reach a large population in a particular geographical region. This is especially the case for the CBIs who reported the 'neighbourhood in general' as one of the settings.

Previous research indicated strengths of elements that could be incorporated within CBIs, such as that the school

Table 2 Additional information about the environmental strategies ${ }^{\mathbf{1}}$

\begin{tabular}{|c|c|}
\hline Actions for parents & $\begin{array}{l}\text { Skill development practices (e.g. cooking healthy, getting skills for reading the food label), increasing knowledge } \\
\text { (e.g. phone counselling connected to family insights about obesity), and access to health care facilities. }\end{array}$ \\
\hline Professional training & Training of health professionals, teachers or other providers of intervention activities. \\
\hline Media attention & $\begin{array}{l}\text { Articles in local media, newspapers, mass media (e.g. TV and radio), public campaigns, flyers, in some cases congresses } \\
\text { or a district health day, and/or provision of general information to raise awareness (e.g. leaflets). }\end{array}$ \\
\hline $\begin{array}{l}\text { Changing the social } \\
\text { environment }\end{array}$ & $\begin{array}{l}\text { Involvement of churches, professors, parents and social actors in creating social networks to stimulate a healthier } \\
\text { environment for children (e.g. folk festivals), provision of social support or funds to stimulate relevant activities as } \\
\text { proposed by community members, signposting to activities in which friendships can be sustained, creating a feeling of } \\
\text { safety by replacing youth that hangs around, improving attitude of teachers (or other role models), involvement of } \\
\text { local stakeholders not related to the health sector }\end{array}$ \\
\hline $\begin{array}{l}\text { Changing the physical } \\
\text { environment }\end{array}$ & $\begin{array}{l}\text { Availability of safe and healthier options for public transportation (e.g. biking lines, walking routes), healthy products in } \\
\text { kindergarten or school canteen, improved schoolyards and playground facilities, construction of safe routes for } \\
\text { promoting active commuting to school, or free provision of healthy foods (milk, fruit). }\end{array}$ \\
\hline Incentives & $\begin{array}{l}\text { Discount on participation in sports or on healthy food, reduced family membership to local leisure services offered to } \\
\text { participating families, available budget for activities organized by the school (resource access) }\end{array}$ \\
\hline Service access & Providing more or improved access to sports or leisure time activities, \\
\hline Regulation & $\begin{array}{l}\text { Agreements between organizations involved or changes in the specific rules about school provided meals, code of } \\
\text { self-regulation of the advertising of food products with the aim of establishing a set of guidelines to help companies } \\
\text { participating in the development, implementation and dissemination of their advertising messages directed at minors. } \\
\text { Contracts for cooperation and mutual support were signed by supporting organizations.; e.g. regulation between } \\
\text { catering services and kindergarden or school }\end{array}$ \\
\hline
\end{tabular}




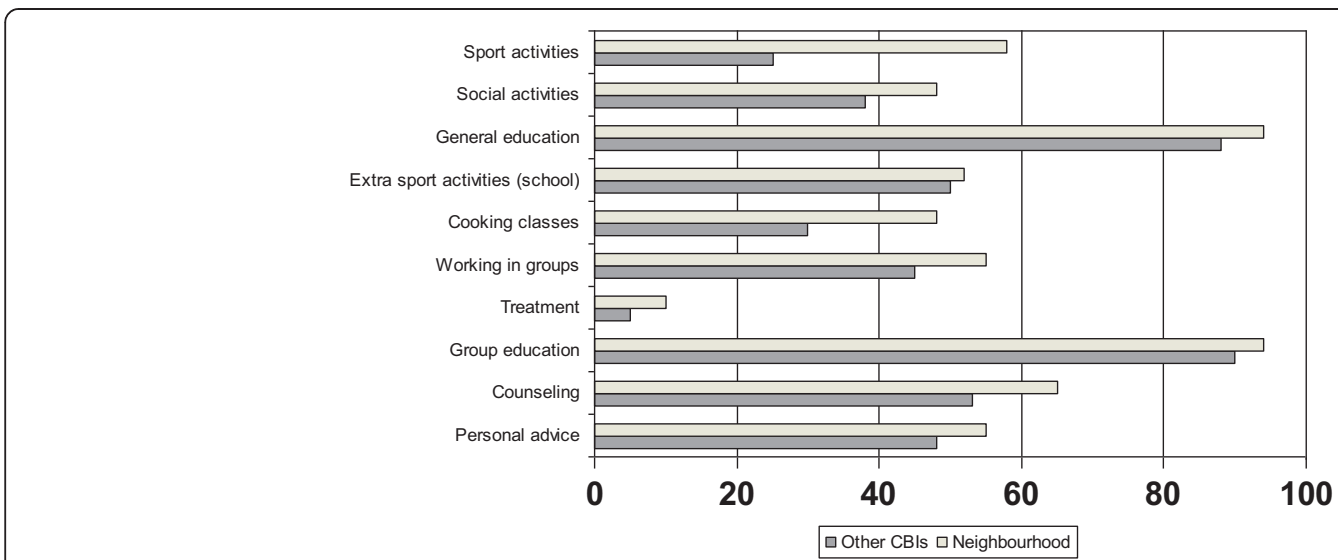

Figure 4 Activities applied in CBIs that report the neighbourhood as one of the settings versus CBls where this was not the case (\%).

can be a pivotal setting for the promotion of healthy weights [36]. According to the educational contents, a physical intervention along with nutrition education and a reduction in TV viewing can effectively combat childhood obesity [37,38]. Furthermore, involvement of parents is crucial by parental modelling and through encouragement and logistic support [38]. Since many of the included CBIs in our overview took the above-mentioned elements into account they seem to have a theoretical basis which optimizes chances for success. For example, $86 \%$ reported a combined focus on nutrition and physical activity. The inclusion criteria for this overview matched to a large extent with the application of so-called social marketing techniques within interventions, which has been suggested as being promising [12]. For example, "customer research" was operationalized as involvement of the target population' and a "methods mix" as 'comprehensive and integrated action'. The current overview certainly adds to the paper by Gracia-Marco et al. [12], which included three European studies only. Gracia-Marco et al. concluded that a higher number of marketing techniques was not associated with effectiveness [12].

\section{Effects of CBIs on weight indicators}

We discuss effectiveness of CBIs separately for preschoolers, 6 to $12 \mathrm{yr}$ old children and adolescents. First we present results from the included CBIs in our survey. Thereafter we compare these findings with other studies, as identified from literature.

According to pre-schoolers, seven of the included CBIs reported young children $(<7$ yrs $)$ as the target population but did not provide information on effectiveness. Skouteris et al. [18] summarized information for eleven studies. Out of these, two studies were performed in Europe. If identified during the overall survey, they would have been considered eligible for this overview. The Tigerkids programme, a German intervention in kindergartens, did not find positive effects on body weight, but the main outcomes were nutrition related [39]. Jouret et al. showed positive effects on overweight prevalence in underprivileged French areas [40]. Hence, we found little evidence among pre-school children for European CBIs. In contrast, an Australian multicomponent community intervention showed substantial reductions in mean BMI (around $0.2 \mathrm{~kg} / \mathrm{m}^{2}$ ) and the prevalence of overweight/ obesity (up to $3 \%$ ) among $3.5 \mathrm{yr}$ old children [41].

According to 6 to $12 \mathrm{yr}$ old children, eight CBIs reported decreased prevalences of overweight in the general population of children, ranging between zero and six percentage points, and a decreased mean BMI up to $1.0 \mathrm{~kg} / \mathrm{m}^{2}$ (Table 3). In addition, Doak et al. [16] suggested effectiveness on weight indicators for four European studies, but these were too old for being eligible for this overview. A Cochrane review involving 55 studies, among which 18 were European, showed a pooled effect on mean BMI of $-0.15 \mathrm{~kg} / \mathrm{m}^{2}$ (stratified by age: -0.26 ( $0-5$ year), -0.15 (6-12 year), -0.09 (13-18 year)) [11]. Out of these 18 studies, ten European RCTs possibly would have been eligible for inclusion in this overview, as coded in Annex 1. Two of these indeed were identified in the overall survey, but not included due to nonresponse to the CBI questionnaire. Both studies showed positive effects on waist circumference (around $-1 \mathrm{~cm}$ ), and on other indicators, but not (significantly) on mean BMI $[42,43]$. In this respect, the BMI reduction in one of the included CBIs, the Children's Study $\left(-1.0 \mathrm{~kg} / \mathrm{m}^{2} ;[25]\right)$, can be considered as exceptionally large. The absence of effect of the Copenhagen Study [23], the only included CBI showing no effect in this age group, may be explained by the exclusive focus on physical activity. Obesity prevention probably requires a combined focus on physical activity and dietary behaviour $[9,17,44]$. In contrast, the included - ICAPs study, also a physical activity intervention, showed a remarkable large reduction in BMI after 4 years [19]. This effect is not supported by other European school based programmes that showed no 
Table 3 Reported effects on weight indicators and overweight prevalence in a general population of children of European community-based interventions

\begin{tabular}{|c|c|c|c|c|c|c|}
\hline Project and design & Age & Sample size (N) & Effect size $(\mathrm{Cl}$ or $\pm \mathrm{SD})$ & p-value & Outcome & Follow-up \\
\hline ICAPS [18] & 12 year & $\mathrm{N}=475$ intervention & $0.3 \mathrm{~kg} / \mathrm{m}^{2}$ & $P=0.05$ & $\Delta \mathrm{BMI}^{2}$ at follow-up & 4 years \\
\hline RCT (randomization at school level) & & $\mathrm{N}=479$ control & & & & \\
\hline \multirow[t]{4}{*}{ Movi $^{1}[20]$} & 8-10 years & $N=375$ intervention & $\begin{array}{l}\text { Boys: intervention: } 30 \% \text { (b) } \\
\text { to } 28 \% \text { (f) }\end{array}$ & & $\begin{array}{l}\text { Prevalence of overweight at baseline (b) } \\
\text { and follow-up ( } f \text { ) }\end{array}$ & 2 years \\
\hline & & $\mathrm{N}=546$ control & control: $33 \%(b)$ to $32 \%$ (f) & & & \\
\hline & & & $\begin{array}{l}\text { Girls: intervention: } 32 \% \text { (b) } \\
\text { to } 26 \%(f)\end{array}$ & & & \\
\hline & & & control: $29 \%$ (b) to $27 \%$ (f) & & & \\
\hline Copenhagen school child [22] & $6-8$ years & $N=243$ intervention & $\begin{array}{l}\text { Boys: intervention: }+9.3 \\
( \pm 3.1) \mathrm{kg}\end{array}$ & $P=0.6$ & Body weight & 3 years \\
\hline \multirow[t]{3}{*}{ Quasi experimental trial } & & $\mathrm{N}=138$ control & control: +9.5 ( \pm 3.4$) \mathrm{kg}$ & & & \\
\hline & & & $\begin{array}{l}\text { Girls: intervention: }+9.0 \\
( \pm 3.1) \mathrm{kg}\end{array}$ & $P=0.5$ & & \\
\hline & & & control: +9.3 ( \pm 3.2$) \mathrm{kg}$ & & & \\
\hline \multicolumn{7}{|l|}{ EPODE [23] } \\
\hline \multirow[t]{3}{*}{ Longitudinal } & 5-12 years & $\begin{array}{l}\text { Boys: } N=421-305- \\
262-312-336\end{array}$ & $\begin{array}{l}\text { Boys: } 9.0 \%-10.2 \%-9.5 \% \\
-7.7 \%-7.4 \%\end{array}$ & & Prevalence overweight at time points: & 12 years \\
\hline & & $\begin{array}{l}\text { Girls: N }=383-296- \\
253-280-297\end{array}$ & $\begin{array}{l}\text { Girls: } 14.1 \%-18.6 \%-17.0 \% \\
-13.6 \%-10.4 \%\end{array}$ & & 1992-2000-2002-2003-2004 & \\
\hline & & & & & Prevalence overweight & \\
\hline \multirow{6}{*}{$\begin{array}{l}\text { Quasi experimental trial (cross-sectional } \\
\text { at endpoint only) }\end{array}$} & $5-12$ years & $N=633$ intervention & Intervention: 8.8\% & $P<0.05$ & BMl & \\
\hline & & $\mathrm{N}=349$ control & Control: $17.8 \%$ & & & \\
\hline & & & Boys: intervention: $15.6 \mathrm{~kg} / \mathrm{m}^{2}$ & $P<0.05$ & & \\
\hline & & & control: $16.7 \mathrm{~kg} / \mathrm{m}^{2}$ & & & \\
\hline & & & Girls: intervention: 15.7 kg/m² & $P<0.05$ & & \\
\hline & & & Control: $16.4 \mathrm{~kg} / \mathrm{m}^{2}$ & & & \\
\hline Children study [24] & 10 year & $N=321$ intervention & Intervention: 2.1 (1.9-2.4) kg & $P=0.1$ & $\Delta$ Body weight & 1 year \\
\hline \multirow[t]{3}{*}{ Clustered RCT (school is level of randomisation) } & & $\mathrm{N}=325$ control & Control: $4.7(4.5-4.9) \mathrm{kg}$ & & & \\
\hline & & & $\begin{array}{l}\text { Intervention: }-1.1 \\
(-1.2--0.9) \mathrm{kg}\end{array}$ & $P<0.05$ & BMl & \\
\hline & & & Control: $+0.1(-0.03-+0.2) \mathrm{kg}$ & & & \\
\hline B-fit [25] & $6-12$ years & $N=539$ & 2008: 17\% (4\%) & & $\begin{array}{l}\text { Prevalence overweight (obesity) at time } \\
\text { points: } 2008-2010\end{array}$ & 2 years? \\
\hline Longitudinal (pre-post test design) & & & 2010: $15 \%(2 \%)$ & & & \\
\hline
\end{tabular}


Table 3 Reported effects on weight indicators and overweight prevalence in a general population of children of European community-based interventions (Continued)

\begin{tabular}{|c|c|c|c|c|c|c|}
\hline \multirow[t]{3}{*}{ GO-Overvecht ${ }^{1}[26]$} & $4-12$ years & $?$ & 2004/05: 26\% & $P<0.05$ & $\begin{array}{l}\text { Prevalence overweight at time points: } \\
\text { 2004/05 - 2008/09 }\end{array}$ & 4 years? \\
\hline & & & 2008/09: 20\% & & & \\
\hline & $\begin{array}{l}12-15 \\
\text { years }\end{array}$ & $N=3532$ & no significant reduction & n.s. & & \\
\hline Slagkracht [27] & 7 years & $N=261(G E)$ & GE: +0.2 & & $\triangle \mathrm{BMI}$ & 1 year \\
\hline \multirow{5}{*}{$\begin{array}{l}\text { Longitudinal (pre-post test design) in two countries } \\
\text { (Germany (GE) and the Netherlands (NL) }\end{array}$} & & $N=296(N L)$ & $\mathrm{NL}:+0.3^{3}$ & & & \\
\hline & & & GE 2009: 15.0\% & & $\begin{array}{l}\text { Prevalence in BMI percentiles } 7 \text { and } 8 \\
\text { (heavy overweight and obesity) }\end{array}$ & $\begin{array}{l}2009- \\
2010\end{array}$ \\
\hline & & & 2010: 14.6\% & & & \\
\hline & & & NL 2009: $12.8 \%$ & & & \\
\hline & & & 2010: $12.0 \%{ }^{5}$ & & & \\
\hline Jönköping County [28] & 6,5 years & $\begin{array}{l}N=3362-3310- \\
3298-3319\end{array}$ & $\begin{array}{l}14 \%(5 \%)-12 \%(4 \%)-15 \% \\
(5 \%)-13 \%(4 \%)\end{array}$ & & $\begin{array}{l}\text { Prevalence overweight (obesity) at time } \\
\text { points: } 2004 / 05-2006 / 07-2009 / 10-2011 / 2012\end{array}$ & 7 years? \\
\hline \multirow[t]{3}{*}{ Cross-sectional } & 10,5 years & $\begin{array}{l}N=4180-3631- \\
3201-3250\end{array}$ & $\begin{array}{l}17 \%(4 \%)-17 \%(3 \%)-17 \% \\
(4 \%)-18 \%(4 \%)\end{array}$ & & & \\
\hline & 14 years & $\begin{array}{l}N=4641-4183- \\
3258-3193\end{array}$ & $\begin{array}{l}15 \%(3 \%)-14 \%(3 \%)-17 \% \\
(5 \%)-17 \%(5 \%)\end{array}$ & & & \\
\hline & 16,5 years & $\begin{array}{l}N=3162-3875- \\
3526-2906\end{array}$ & $\begin{array}{l}15 \%(4 \%)-15 \%(3 \%)-14 \% \\
(4 \%)-16 \%(6 \%)\end{array}$ & & & \\
\hline
\end{tabular}

${ }^{1}$ Study design involving comparison with a control region/condition; ${ }^{2} \mathrm{BMI}=$ Body Mass Index ${ }^{3}$ corresponding with normal effects of growth, according to the authors; ${ }^{4}$ prevalence of percentile 8 (obesity) increased from 3.3 to $4.2 \%$. 
Table 4 Reported effects on body weight and prevalence of overweight in overweight or obese children

\begin{tabular}{|c|c|c|c|c|}
\hline \multirow[t]{2}{*}{ Name project, design trial } & \multirow[t]{2}{*}{ Age participants/sample size } & \multirow{2}{*}{$\begin{array}{l}\text { Results } \\
\text { Effect size } / \%(\mathrm{Cl} \\
\text { or } \mathrm{p} \text { value) }\end{array}$} & \multirow[b]{2}{*}{ Outcome } & \multirow[b]{2}{*}{ Follow-up } \\
\hline & & & & \\
\hline Alive 'n'Kicking [29] & $4-6$ years & $-0,8 / 3,4 \%$ & $\mathrm{BMI}^{1}$ & 12 wks \\
\hline \multirow{6}{*}{$\begin{array}{l}\text { Pretest/posttest comparison without control group } \\
\text { (children who started the program) }\end{array}$} & $7-11$ years & $0,6 / 2,5 \%$ & & \\
\hline & $12-15$ years & $-0,3 / 0,9 \%$ & & \\
\hline & $4-6$ years & $-2,7 / 3,6 \%$ & $\begin{array}{l}\text { Waist Circumference } \\
(\mathrm{cm})\end{array}$ & \\
\hline & $7-11$ years & $-2,0 / 2,3 \%$ & & \\
\hline & $12-15$ years & $-5,4 / 6,0 \%$ & & \\
\hline & $\mathrm{N}=389$ started // 309 completers & & & \\
\hline $\begin{array}{l}\text { Integrated Obesity Care Pathway - A Whole } \\
\text { Systems Approach }\end{array}$ & 7-17 years & $+0,8$ & Body weight & 1 year \\
\hline Pre post test design (completers of program) & $N=48$ & $-0,9(p<0,05)$ & & \\
\hline Mend $[30,31]$ & $8-12$ years & & & \\
\hline \multirow[t]{7}{*}{ RCT } & $N=37$ intervention & $\begin{array}{l}-1.2(-1.8 \text { to }-0.6) \\
p<0,001\end{array}$ & $\triangle \mathrm{BMl}$ & 6 months \\
\hline & $\mathrm{N}=45$ control & $\begin{array}{l}-4,1(-5,6 \text { to }-2,7) \\
p<0,001\end{array}$ & $\begin{array}{l}\triangle \text { Waist } \\
\text { circumference }\end{array}$ & \\
\hline & $N=42$ intervention & $-0,1(-0,7-+0,4)$ & BMl & 12 months \\
\hline & & $-3,1(-4,6--1,6)$ & Waist circumference & \\
\hline & $7-13$ years & & & \\
\hline & $\begin{array}{l}\mathrm{N}=9754 \text { intervention }(\mathrm{N}=6815 \\
\text { complete measurements) }\end{array}$ & $-0,18$ & BMl z score & 10 weeks \\
\hline & & $-0,22$ & $\begin{array}{l}\text { Waist circumference } \\
\text { z score }\end{array}$ & \\
\hline Fun 4 Life $^{2}$ & $8-16$ years & $-0,3$ & Body weight & 3 months \\
\hline Pre post test design (completers of program) & $N=63$ & $-0,5$ & BMl & \\
\hline \multirow[t]{2}{*}[32]{} & 8-15 years & No effect & BMl & 12 weeks \\
\hline & $N=19$ & & & \\
\hline
\end{tabular}

${ }^{1} \mathrm{BMI}=$ Body Mass Index; ${ }^{2} \mathrm{e}$-mail information.

[44-46] or ambiguous results [47]. Obviously, in case of no effect on body weight, positive effects on other health indicators can be substantial, as shown by the favourable impact on bone minerals in girls by the Copenhagen Study [23]. Furthermore, as by definition, the effects of a CBI can expand beyond the children. Paineau et al. showed a positive BMI effect among the parents, but not among the children [48]. According to adolescents, two of the included CBIs $[27,29]$ found no effects on weight indicators. This is in line with the above-mentioned Cochrane review [11] suggesting smaller effects in this age group, as compared to younger children.

\section{Overweight children versus general population}

Two of the CBIs [19,23] found smaller effects among overweight children as compared to healthy weight children at baseline, suggesting that additional intervention is required for weight reduction instead of preventing weight gain in a general population of children. According to effects in overweight or obese children, four CBIs (all United Kingdom) reported beneficial effects, ranging between 0.3 and $1.2 \mathrm{~kg} / \mathrm{m}^{2}$ on the short term. However, after one year no positive effect on BMI has been shown, although the MEND Study found a positive effect on waist circumference [31]. Furthermore, study designs of the included CBIs were of low quality. This was also pointed out in a Cochrane review including 64 RCTs [17]. Among the 54 studies focusing on lifestyle therapy in children, 12 were European ones. Two of them showed a BMI reduction of $0.2 \mathrm{~kg} / \mathrm{m}^{2}$ after six months (as compared to a nonsignificant reduction of $0.1 \mathrm{~kg} / \mathrm{m}^{2}$ in the MEND Study after 1 year). The effects did not significantly differ from usual health care procedures $[49,50]$, underpinning that collaboration with the health care system, including optimal referral procedures, will provide possibilities to combine a low risk population based approached with an intensified 
Table 5 Specific objectives for nutrition, physical activity and body weight of $\mathbf{1 3}$ community-based interventions that provided information on effectiveness

\begin{tabular}{|c|c|c|c|c|c|c|c|c|c|c|c|c|c|c|c|c|}
\hline \multirow[t]{3}{*}{ Name project (reference) } & \multirow[t]{3}{*}{ Effects $^{1}$} & \multirow[t]{3}{*}{ Period $^{2}$} & \multicolumn{14}{|c|}{$\begin{array}{l}\text { Topics activities were targeted at (see below for } \\
\text { the legend): }\end{array}$} \\
\hline & & & \multicolumn{4}{|c|}{ Nutrition } & \multicolumn{5}{|c|}{ Physical activity } & \multicolumn{5}{|c|}{ Body weight } \\
\hline & & & A1 & A2 & A3 & A4 & $\mathrm{B1}$ & B2 & B3 & B4 & B5 & $\mathrm{C} 1$ & $\mathrm{C} 2$ & $\mathrm{C} 3$ & C4 & $C 5$ \\
\hline \multicolumn{17}{|l|}{ General population : } \\
\hline ICAPS [18] & + & 2011-14 & & & & & * & * & * & & & & & & & \\
\hline Movi [19] & + & 2004-06 & & & & & & & $*$ & & $*$ & $*$ & $*$ & & & \\
\hline Copenhagen school child $[22]^{3}$ & - & 2001-08 & & & & & & & & & & & & & & \\
\hline EPODE [23] & + & 2004-14 & * & * & * & * & & * & * & & & & & & & \\
\hline Children study [24] & + & 2005-06 & * & & * & * & & & * & & * & * & * & & * & * \\
\hline B-fit [25] & + & 2008- & & * & * & * & * & & * & & & * & & & & * \\
\hline GO-Overvecht [26] & + & $2005-10$ & & * & * & * & & & & * & & & & & & \\
\hline Slagkracht [27] & + & 2010-12 & * & * & * & * & * & & * & * & & * & * & * & * & * \\
\hline Jönköping county [28] & $+?$ & $2004-$ & * & * & * & * & * & * & * & $*$ & * & * & * & * & * & * \\
\hline \multicolumn{17}{|l|}{ Overweight or obese children: } \\
\hline Alive 'n'Kicking [29] & + & $2006-$ & * & * & * & * & * & * & * & * & * & * & * & * & * & * \\
\hline Integrated Obesity Care Pathway - A Whole Systems Approach & + & $2005-$ & * & * & * & * & & & & & & * & * & * & * & * \\
\hline MEND $[30,31]$ & + & 2004-11 & * & * & * & * & * & * & * & * & * & * & * & * & * & * \\
\hline Fun 4 life [32] & $+/-$ & 2004- & * & * & * & * & * & * & * & * & * & * & * & * & $*$ & $*$ \\
\hline \multicolumn{17}{|c|}{$\begin{array}{l}\text { 1Effects on body weight, BMI, and/or overweight prevalence (+is positive effects; }- \text { is no effect); }{ }^{2} \text { Period of implementation of CBI activities (note: not necessarily } \\
\text { the same as the period that the research was performed regarding effectiveness); }{ }^{3} \text { reported a focus on "physical activity in general"; } \\
\text { Objectives nutrition: A1 = Healthy diet in general, A2 = food intake patterns, A3 = Single food items (e.g. fruits), A4 = High caloric foods. } \\
\text { Objectives Physical activity: B1 = Sports/exercise, B2 = Walking and/or cycling, B3 = Outdoor play, B4 = TV watching ,B5 = Cardiorespiratory fitness. } \\
\text { Objectives body weight:C1 = Energy balance in general (involving both diet and physical activity), C2 = Psychological aspects (self esteem), C3 = Preventing } \\
\text { unhealthy slimming behaviour, C4 = (Preventing) stigmatizing of children having obesity (e.g. bullying), C5 = Improving coping skills, empowerment of children } \\
\text { (e.g. increasing awareness of obesogenic influences by TV commercials). }\end{array}$} \\
\hline
\end{tabular}

care pathway for obese children. In our overview, 35 CBIs (49\%) reported collaboration with medical doctors in the usual health care system.

\section{Contribution of CBIs in curbing the obesity epidemic}

In summary, our overview suggests effectiveness of eight CBIs in 6 to 12 yr old children in the general population. Little evidence was found for pre-schoolers and adolescents. Regarding assessing effectiveness of CBIs, the optimal study design would be comparing the development of body weight of the children in the particular CBI area with the children in a control region without CBI activities, preferably by using a large randomly selected sample of children and a follow up of several years. These data, however, appear to be scarcely available. Quality of research methodology of most included CBIs is suboptimal (especially for overweight children) i.e. no control group, a small sample size, and not random. Therefore, the evidence regarding effectiveness should be considered as an indication.

When reflecting on the contribution of CBIs in curbing the obesity epidemic among European children, besides insight in effectiveness, also the number of children reached is of importance. Overall, a minority of
CBIs reported this information for the various strategies [14]. Based on the ones who did, we estimated that 700.000 children have been reached by counselling sessions, 300,000 attended cooking classes and 240,000 received free healthy foods within included CBIs. Since the $71 \mathrm{CBI}$ are a subsample of all CBIs, and since most countries have national action plans against obesity, promoting these local strategies also outside the context of a "CBI", this certainly is an underestimation. Although a substantial amount of children may have been reached, this still is a small part of the total number of 110 million European children. So it is hard to conclude on the potential contribution of CBIs in curbing the obesity epidemic on a European scale. Potential impact of obesity preventive programmes may better be studied country specific, and some positive signals became available [51].

\section{Methodological considerations of the overall survey}

Some methodological limitations in the overall survey design, resulting from the specifications for the study as defined by the EC, should be discussed, since these determined the initial selection of potentially eligible projects that have been approached with the CBI questionnaire. The timeframe was tight and key informants 
indicated that they had reported primarily on the most important CBIs. Related to the second step in data collection (the CBI questionnaire), the deadline fell inside the summer holidays. This negatively affected the response rate, as well as the fact that the questionnaire could be completed in English only and was quite extensive. On the other hand, with respect to effectiveness hardly any project could be added after screening the recent reviews $[11,12]$. We clearly identify this as a gap in information.

Because of the above-mentioned limitations, the overview of CBIs collected in this survey will not be fully representative for the total of CBIs applied in the EU. However, the aim of the study was not necessarily to make a representative overview, but to collect good practice examples. Moreover, even without being fully representative, the detailed information gathered in the survey on 71 European projects [14] has clear added value, as such a comprehensive overview did not yet exist. Despite diversity of included European CBIs, common characteristics were seen regarding the application of integrated actions at a local level, aimed at changing the environment and the children's behaviour directly. For comparing effects of CBI (strategies) we stress the need for a standardization of evaluation methodology and data collection. The IDEFICS project, which is executed in eight European countries, may serve as an example for this in the future [52].

\section{Conclusions}

Despite diversity of the CBIs included in our study, common characteristics were the application of integrated actions at a local level, aimed at changing both the environment and the children's behaviour directly. Evidence supporting effectiveness on weight indicators is available, for a general population of 6 to $12 \mathrm{yr}$ old children, although the design and conduct of these studies were suboptimal (i.e. no control group, a small sample size, not random)l.

\section{Additional files}

Additional file 1: List of potentially suitable projects. Description data: Overview of all the 278 potentially suitable projects identified for the survey together with the method with which they were identified, whether they filled in the questionnaire, and if so, whether they met all inclusion criteria. Information from a Cochrane review on preventive programmes targeting childhood obesity (reference no. 11) was added to this overview.

Additional file 2: List of excluded projects and reasons. Description data: Overview of projects that were excluded for analysis and the reasons for exclusion.

\section{Abbreviations}

BMI: Body Mass Index; CBI: community-based initiative; EC: European Commission; EU: European Union; RCT: randomized clinical trial; RIVM: National Institute of Public Health and the Environment of the Netherlands; WHO: World Health Organization.

\section{Competing interests}

The authors declare that they have no competing interests.

\section{Authors' contributions}

WB is the main author of the article. TW, JB and MV have reviewed several draft versions of the manuscript. All authors read and approved the final manuscript.

\section{Acknowledgements}

We greatly acknowledge all contributors to this survey, who are individually mentioned in the report for the EC [14]. Furthermore, we would like to thank our RIVM colleagues Manon Savelkoul, Wanda Vos and Joop van Raaij, who helped us perform the survey described in this paper, and we acknowledge the help of Daphne van der A in revising the manuscript. Finally, we thank Diana Pirjol, who worked as an intern at RIVM, and made a large contribution to collecting the data on effectiveness. This study was funded by the EC, Specific contract - No SC 201062 51, implementing Framework Contract No EAHC/2010/Health/01 (Lot 1).

\section{Disclaimer}

João Breda and Trudy Wijnhoven are staff members of the WHO Regional Office for Europe. The authors alone are responsible for the views expressed in this publication and they do not necessarily represent the decisions or the stated policy of the WHO. The views expressed in this article do not necessarily reflect the official position of the EC. Neither the Commission nor any person acting on its behalf can be held responsible for any use that may be made of the information in this article.

\section{Author details}

${ }^{1}$ National Institute for Public Health and Environment (RIVM), Bilthoven, the Netherlands. ${ }^{2}$ Noncommunicable Diseases and Life-Course, World Health Organization Regional Office for Europe, UN City, Marmorvej 51, DK-2100 Copenhagen, Denmark. ${ }^{3}$ The National Institute for Public Health and Environment, Centre for a Healthy Living, PO Box 1, 3720, BA Bilthoven, The Netherlands.

Received: 19 July 2013 Accepted: 1 July 2014

Published: 28 July 2014

\section{References}

1. Finucane MM, Stevens GA, Cowan MJ, Danaei G, Lin JK, Paciorek CJ, Singh GM, Gutierrez HR, Lu Y, Bahalim AN, Farzadfar F, Riley LM, Ezzati M, on behalf of the Global Burden of Metabolic Risk Factors of Chronic Diseases Collaborating Group (Body Mass Index): National, regional, and global trends in body-mass index since 1980: systematic analysis of health examination surveys and epidemiological studies with 960 country-years and 9.1 million participants. Lancet 2011, 377:557-567.

2. Global status report on noncommunicable diseases 2010. Geneva: World Health Organization; 2011 [http://whqlibdoc.who.int/publications/2011/ 9789240686458_eng.pdf, accessed May 2014]

3. Wijnhoven TMA, van Raaij JMA, Spinelli A, Rito Al, Hovengen R, Kunesova M, Starc G, Rutter H, Sjöberg A, Petrauskiene A, O'Dwyer U, Petrova S, Farrugia Sant'Angelo V, Wauters M, Yngve A, Rubana I-M, Breda J: WHO European Childhood Obesity Surveillance Initiative 2008: weight, height and body mass index in 6-9-year-old children. Pediatr Obes 2013, 8(2):79-97.

4. White Paper on a strategy for Europe on nutrition, overweight and obesity related health issues. Brussels: European Commission; 2007.

5. European Charter on Counteracting Obesity. Copenhagen: WHO Regional Office for Europe; 2006 [http://www.euro.who.int/data/assets/pdf_file/0009/ 87462/E89567.pdf, accessed April 2014].

6. Joint $\mathrm{WHO} /$ European Commission project to monitor progress in improving nutrition and physical activity and preventing obesity in the European Union [website]. [http://www.euro.who.int/en/health-topics/diseaseprevention/nutrition/activities/monitoring-and-surveillance/joint-whoecproject-to-monitor-progress, accessed April 2014].

7. Birch LL, Ventura AK: Preventing childhood obesity: what works? Int J Obes 2009, 33:74-81

8. Ebbeling CB, Pawlak DB, Ludwig DS: Childhood obesity: public health crisis, common sense cure. Lancet 2002, 360:473-482.

9. Branca F, Nikogosian H, Lobstein T: The challenge of obesity in the WHO European Region and the strategies for response. Copenhagen: WHO Regional 
Office for Europe; 2007 [http://www.euro.who.int/_data/assets/pdf_file/ 0010/74746/E90711.pdf, accessed May 2014]

10. Ardakani AA: Community-based initiatives and their relation to poverty reduction and health development: experiences in the Eastern Mediterranean Region. La Revue de Santé de la Méditerranée orientale 2007, 13(6):1242-1248.

11. Waters E, De-Silva-Sanigorski A, Hall BJ, Brown T, Campbell KJ, Gao Y, Armstrong R, Prosser L, Summerbell CD: Interventions for preventing obesity in children. Cochrane Database Syst Rev 2011. Issue 12. Art. No.: CD001871. doi:10.1002/14651858.CD001871.pub3.

12. Gracia-Marco L, Vicente-Rodriguez G, Borys JM, Le Bodo Y, Pettigrew S, Moreno LA: Contribution of social marketing strategies to community-based obesity prevention programmes in children. Int J Obes 2011, 35:472-479.

13. Kuipers YM: Focusing on obesity through a health equity lens, A collection of innovative approaches and promising practices by European and international health promotion bodies to counteract obesity and improve health equity. Brussels: EuroHealthNet; 2010.

14. Bemelmans WJE, Verschuuren M, van Dale D, Savelkoul M, Wendel-Vos GCW, van Raaij J: An EU-wide overview of community-based initiatives to reduce childhood obesity. RIVM: Bilthoven; 2011.

15. WHO Regional Office for Europe, European Commission: Report of the meeting on community initiatives to improve nutrition and physical activity. Copenhagen: WHO Regional Office for Europe; 2010 [http://www.euro.who.int/ __data/assets/pdf_file/0005/87422/E93702.pdf?ua=1, accessed April 2014].

16. Doak CM, Visscher TL, Renders CM, Seidell JC: The prevention of overweight and obesity in children and adolescents: a review of interventions and programmes. Obes Rev 2006, 7:111-136.

17. Oude Luttikhuis H, Baur L, Jansen H, Shrewsbury VA, O'Malley C, Stolk RP Summerbell CD: Interventions for treating obesity in children (review). Cochrane Database Syst Rev 2009, 3:1-57.

18. Skouteris H, McCabe M, Swinburn B, Newgreen V, Sacher P, Chadwick P: Parental influence and obesity prevention in pre-schoolers: a systematic review of interventions. Obes Rev 2010, 12:315-328.

19. Simon C, Wagner A, Platat C, Arveiler D, Schweitzer B, Schlienger JL, Triby E: ICAPS: a multilevel program to improve physical activity in adolescents. Diabetes Metab 2006, 32:41-49.

20. Markert A, Alff F, Zschaler S, Gausche R, Kiess W, Blüher S: Prevention of childhood obesity: Recruiting strategies via local paediatricians and study protocol for a telephone-based counselling programme. Obes Res Clin Pract in press.

21. Salcedo Aguilar F, Martínez-Vizcaíno V, Sánchez López M, Solera Martínez M, Franquelo Gutiérrez R, Serrano Martínez S, López-García E, RodríguezArtalejo F: Impact of an after-school physical activity program on obesity in children. J Pediatr 2010, 157(1):36-42. e3.

22. Sahota P, Rudolf MCJ, Dixey R, Hill AJ, Barth JH, Cade J: Randomised controlled trial of primary school based intervention to reduce risk factors for obesity. Br Med J 2001, 323:1029-1032.

23. Hasselstrom HA, Karlsson MK, Hansen SE, Gronfeldt V, Froberg K, Andersen LB: A 3-year physical activity intervention program increases the gain in bone mineral and bone width in prepubertal girls but not boys: the prospective Copenhagen School Child Interventions Study (CoSCIS). Calcif Tissue Int 2008, 83:243-250.

24. Romon M, Lommez A, Tafflet M, Basdevant A, Oppert JM, Bresson JL, Ducimetière $\mathrm{P}$, Charles MA, Borys JM: Downward trend in the prevalence of childhood overweight in the setting of 12-year school- and community based programmes. Publ Health Nutr 2009, 12:1735-1742.

25. Angelopoulos PD, Milionis HJ, Grammatikaki E, Moschonis G, Manios Y: Changes in $\mathrm{BMI}$ and blood pressure after a school based intervention: the CHILDREN study. Eur J Public Health 2009, 19(3):319-325.

26. Schokker DF, van PE E, Verheijden MW: Eindrapportage Overgewicht, BOFTgedrag en determinanten bij leerlingen op B-fit scholen, TNO/LS 2012 R11028 [TNO: overweight reduction through B-Fit]. [http://www.geldersesportfederatie. nl/nieuws/EindrapportTNOprogrammaBFit.pdf ] [in Dutch]

27. Oosterman J, Schreurs H, Groeneboom G, Hillen S, Geus de G, Goot van der K, Ameijden van E: Eindevaluatie Gezond Gewicht Overvecht. 2011 [http://www. utrecht.n//images/Gggd/gezondheidsbevordering/Gezond Gewicht/100701. eindevaluatie\%20GO.pdf] [in Dutch].

28. Naul R, Schmelt D, Dreiskaemper D, Hoffmann D, l'Hoir M: 'Healthy children in sound communities'(HCSC/gkgk)- a Dutch-German community-based network project to counteract obesity and physical inactivity. Fam Pract 2012, 29(Suppl 1):i110-i116.
29. Eriksson M: Övervikt och fetma bland barn och ungdomar i Jönköpings län. 2012 [http://www.lj.se/info_files/infosida32826/ overvikt_och_fetma_bland_barn_2013_publ_140221.pdf] [in Swedish].

30. Alive ' $n$ ' Kicking Childhood Obesity Intervention Results 2009-2011. [http://www.wmc.uk.com/wp-content/uploads/2011/07/Alive-n-KickingEvaluation-Report-2009-2011-NEW.pdf]

31. Sacher PM, Kolotourou M, Chadwick PM, Cole TJ, Lawson MS, Lucas A, Singhal A: Randomized controlled trial of the MEND program: A family-based community intervention for childhood obesity. Obesity 2010, 18(Suppl 1):S62-S68.

32. Sacher PM, Chadwick P, Kolotourou M, Radley D, Chipperfield A, Stevenson A, Cole TJ, Lawson M, Lucas A, Singhal A: From clinical trial to large-scale community implementation: evaluation of the MEND multicomponent, family-based, child weight management programme in overweight and obese 7-13 year old children in the United Kingdom. Obes Rev 2010, 11(Suppl 1):88.

33. Assessment of the effectiveness of a community weight management programme for overweight and obese children. Fun4life; 2006 [http://www. fun4life.org.uk/wp-content/uploads/2009/09/Carnegie-Club-Report-WalsallPool-Hayes-2006-WAY-COPY.pdf, accessed May 2014].

34. Swinburn B, Egger G, Raza F: Dissecting obesogenic environments: the development and application of a framework for identifying and prioritizing environmental interventions for obesity. Prev Med 1999, 29:563-570

35. Flynn MA, McNeil DA, Maloff B, Mutasingwa D, Wu M, Ford C, Tough SC: Reducing obesity and related chronic disease risk in children and youth: a synthesis of evidence with 'best practice' recommendations. Obes Rev 2006, 7(Suppl 1):7-66.

36. Vleugelers PJ, Fitzgerald AL: Effectiveness of school programs in preventing childhood obesity: a multilevel comparison. AM J Publ health 2005, 95:432-435.

37. Katz DL, O'Connell M, Njike VY, Yeh M-C, Nawaz H: Strategies for the prevention and control of obesity in the school setting: systematic review and meta-analysis. Int J Obes 2008, 32:1780-1789.

38. Nixon CA, Moore HJ, Douthwaite W, Gibson EL, Vogele C, Kreichauf S, Wildgruber A, Manios Y, Summerbell CD, and ToyBox-study group: Identifying effective behavioural models and behaviour change strategies underpinning preschool- and school-based obesity prevention interventions aimed at 4-6-year-olds: a systematic review. Obes Rev 2012, 13(Suppl 1):106-117.

39. Bayer O, von Kries R, Strauss A, Mitschek C, Toschke AM, Hose A, Koletzko $B V$ : Short- and mid-term effects of a setting based prevention program to reduce obesity risk factors in children: A cluster-randomized trial. Clin Nutr 2009, 28:122-128.

40. Jouret B, Ahluwalia N, Dupuy M, Cristini C, Negre-Pages L, Grandjean H, Tauber M: Prevention of overweight in preschool children: results of kindergarten-based interventions. Int J Obes 2009, 33:1075-1083.

41. Silva-Sanigorski AM, Bell AC, Kremer P, Nichols M, Crellin M, Smith M, Sharp S, Groot de F, Carpenter L, Boak R, Robertson N, Swinburn BA: Reducing obesity in early childhood: results from Romp \& Chomp, an Australian community-wide intervention program. Am J Clin Nutr 2010, 91:831-840.

42. Jansen W, Borsboom G, Meima A, Joosten-van Zwanenburg E, Mackenbach J, Raat H, Burg J: Effectiveness of a primary school-based intervention to reduce overweight. Int J Pediatr Obes 2011, 6(2-2):e70-e77.

43. Puder JJ, Marques-Vidal P, Schindler C, Zahner L, Niederer I, Burgi F, Ebenegger V, Nydegger A, Kriemler S: Effect of multidimensional lifestyle intervention on fitness and adiposity in predominantly migrant preschool children (Ballabeina): cluster randomised controlled trial. BMJ 2011, 13;343:d6195.

44. Reilly JJ, Kelly L, Montgomery C, Williamson A, Fisher A, McColl JH, Conte RL, Paton JY, Grant S: Physical activity to prevent obesity in young children: cluster randomised controlled trial. BMJ 2006, 18;333(7577):1041.

45. Kipping RR, Payne C, Lawlor DA: Randomised controlled trial adapting US school obesity prevention to England. Arch Dis Child 2008, 93:469-473.

46. Harrison M, Burns CF, McGuinness M, Heslin J, Murphy NM: Influence of a health education intervention on physical activity and screen time in primary school children: 'Switch Off-Get Active'. J Sci Med Sport 2006, 9(5):388-394.

47. Lazaar N, Aucouturier J, Ratel S, Rance M, Meyer M, Duche P: Effect of physical activity intervention on body composition in young children: influence of body mass index status and gender. Acta Paediatr 2007, 96(9):1315-1320. 
48. Paineau D, Beaufils F, Boulier A, Cassuto D, Chwalow J, Combris P, Couet $C$ Jouret B, Lafay L, Laville M, Mahe S, Ricour C, Romon M, Simon S, Tauber M, Valensi P, Chapalain V, Zourabichvili O, Bornet F: Family Dietary Coaching to Improve Nutritional Intakes and Body Weight Control. A Randomized Controlled Trial. Arch Pediatr Adolesc Med 2008, 162(1):34-43.

49. Hughes AR, Stewart L, Chapple J, McColl JH, Donaldson MDC, Kelnar CJH, Zabihollah M, Ahmed F, Reilly Jj: Randomized controlled trial of a best-practice individualized behavioural of childhood overweight: Scottish childhood overweight treatment trial (SCOTT). Pediatrics 2008, 121:e539-e546.

50. Kalavainen MP, Korppi MO, Nuutinen OM: Clinical efficacy of group based treatment for childhood obesity compared with routinely given individual counseling. Int J Obes 2007, 31(10):1500-1508.

51. Bluher S, Meigen C, Gausche R, Keller E, Pfaffle R, Sabin M, Werther G, Odeh R, Kiess W: Age-specific stabilization in obesity prevalence in German children: A cross-sectional study from 1999 to 2008. Int J Pediatr Obes 2011, 6(2-2):e199-e206.

52. Ahrens W, Bammann K, Siani A, Buchecker K, De Henauw S, lacoviello L, Hebestreit A, Krogh V, Lissner L, Marild S, Molnár D, Moreno LA, Pitsiladis YP, Reisch L, Tornaritis M, Veidebaum T, Pigeot I on behalf of the IDEFICS Consortium: The IDEFICS cohort: design, characteristics and participation in the baseline survey. Int J Obes 2011, 35(Suppl 1):S3-S15.

doi:10.1186/1471-2458-14-758

Cite this article as: Bemelmans et al:: Overview of 71 European community-based initiatives against childhood obesity starting between 2005 and 2011: general characteristics and reported effects. BMC Public Health 2014 14:758.

\section{Submit your next manuscript to BioMed Central and take full advantage of:}

- Convenient online submission

- Thorough peer review

- No space constraints or color figure charges

- Immediate publication on acceptance

- Inclusion in PubMed, CAS, Scopus and Google Scholar

- Research which is freely available for redistribution 